\title{
VARIETY CHARACTERISTICS AND CASSAVA ADOPTION AMONG RURAL HOUSEHOLDS IN IMO STATE.
}

\author{
Onu D.O and Ohajianya D.O
}

\begin{abstract}
This study investigated the factors contributing to low levels of adoption of improved cassava varieties in Imo State. A sample of 120 respondents was randomly selected for the study and interviewed using structured questionnaire. Empirical analysis was based on a farm household model, which explicitly incorporates variety characteristics into the households' optimization process. A multitude of variety characteristics and some household socio economic characteristics were considered. Results indicated that certain variety and economic characteristics are important determinants of variety choice, and that inadequate extension information and improved input distribution system may be important limiting factors to adoption of improved cassava varieties.
\end{abstract}

\section{Key words: Variety Characteristics, Cassava Adoption, rural households}

\section{INTRODUCTION}

Cassava (Manihot esculenta Crants) is grown throughout sub-Saharan Africa and it is second to maize as human staple, accounting for more than 200 calories per day per person (IITA,1998) . About 160 million people ,or $40 \%$ of the population, consume cassava as a staple food (Nweke et al, 1998). The ability of cassava to produce economic yields under the marginal production conditions characteristic of Africa (poor management, low soil fertility, low input use) has made it the preferred crop for resource poor farmers in much of the region (Polson and Spencer, 1992) Its role as a major economic and food security crop has generated significant research interest at the national and international levels over the last two decades. It plays such a crucial role because of its efficient production of food energy, yearround availability, tolerance to stress and suitability for present farming systems (Polson and Spencer, 1992).

The international institute of Tropical Agriculture (IITA) has given high priority to research on the improvement of cassava germplasm for Africa's diverse production ecologies (IITA, 1998). Major cassava varieties diffused in Imo State of Nigeria through the natural agricultural systems (NARS) include the tropical manihot series (TMS) 30572,4 (2) 1425, and 30555 originally developed by IITA (IITA, 1987). These varieties are high yielding and resistant to common cassava diseases, such as bacterial blight and mosaic virus. Local cassava varieties in Imo State are low yielding and highly susceptible to sporadic outbreaks of these diseases. Adoption rates of the improved cassava varieties by farmers in Imo State has remained below expectation, however despite the potential economic benefits from adoption.

Adoption rates, measured as the proportion of farms planted to the new varieties, range from 5 to $80 \%$ for adjacent farming communities (Nweke et at, 1998). These wide range in adoption rates imply that the farmers differ in the relative importance they attach to the new varieties, a trend that reflects the different opportunity costs of adoption Equally, the level of adoption of improved cassava varieties is below 40\% (Polson and Spencer, 1992).

Thus, for extension efforts to optimize their impact, it is essential to understand the factors contributing to these low levels of adoption of improved cassava varieties in Imo State. Yet little empirical information of that kind exists in Imo State.

Our empirical work was based on a farm household model that explicitly 
incorporates variety characteristics into the household's optimization process. We considered a multitude of agronomic characteristics (e.g., drought resistance, disease resistance pest resistance, stand establishment, tuber size, tuber number, early maturity, harvesting ease, taste of cassava products and gari quality ) that are valued by farmers, as well as an array of household socioeconomic characteristics .

The study specifically examines the types of cuttings planted by farmers, cassava production and yields, analyzes farmers assessment of cassava varieties and characteristics, and estimates the determinants of variety choice in the State.

\section{METHODOLOGY}

The study was conducted in six of the 27 Local Government Areas (LGA's) of Imo State . Ahiazu- Mbaise, Ngor-Okpala, Isiala Mbano, Ihite-Uboma, Ideato-North and Oru-West . These were purposively selected to cover three different systems of cassava farming (Zero tillage, mounds, and ridges) in Imo State. A survey of the production practices and household socioeconomic characteristics of cassava farmers in these six LGAs was conducted during the 2003/2004 cropping year. Two communities were purposively selected from each LGA and 10 households were randomly selected from each community, giving a sample size of 120 households.The resident extension agents and key informants prepared the sampling frame for selection of the households.

Data were collected with structured questionnaire from the household heads on their cultivation practices, farming systems, planting decisions, input use, and output obtained regarding their cassava crops planted in the 2003/2004 cropping year, as well as some retrospective information for the 2001/2002 cropping year.

Major crops planted in the study area are cassava, yam, cocoyam, maize, rice, plantains, etc.

\section{Analytical framework and techniques.}

The empirical analysis adopted in this work is based on a farm household model that generates testable hypotheses concerning the role of variety characteristics in determining farm households' varietal choice (Hintze, 2002, Renkow et al, 2003). The model is very useful as a tool for studying different circumstances faced by farmers and different problems encountered in the content of variety adoption (Hintze et al, 2003).

Consider a household that gains utility through cultivation of an array of cassava characteristics $\left(\mathrm{X}^{0}\right)$, as well as two other arable crops $(\mathrm{K})$ and $(\mathrm{L})$. The household does not acquire these characteristics directly, rather, they are contained in varying amounts by $n$ different varieties of cassava. Let $\mathrm{c}$ be the $\mathrm{n}$ - vector of varieties cultivated. Each variety, $i$ is assumed to contain different quantities of $m$ different characteristics $\left(\mathrm{z}_{1}, \ldots \ldots, \mathrm{z}_{\mathrm{m}}\right)$.

The combinations of characteristics provided by each variety are assumed to be non -stochastic and completely observable by farm households. Following Ladd and Suvannunt (1976), $Z_{j}$ is defined as the amount of characteristics $j$ possessed by a unit of variety $i$, and $Z_{n j}$ is denoted as the total amount of characteristics $j$ cultivated by the household.

Household utility is defined by the $Z_{n j}$ 's which are, in turn, functions of the $C_{i}$ 's: $\mathrm{U}=\mathrm{U}\left(\mathrm{Z}_{\mathrm{nj}}(\mathrm{c}), \mathrm{Z}_{\mathrm{n} 2}(\mathrm{c}) \ldots \ldots \ldots \ldots \mathrm{Z}_{\mathrm{nm}}(\mathrm{c}), \mathrm{k}, \mathrm{L}\right)$.

The household is assumed to allocate a fixed amount of land among $\mathrm{n}$ different varieties of cassava plus one cash crop. We assumed constant non-stochastic yields per hectare, so that choices over the area planted to each variety are equivalent to choices over the quantity harvested. Implicit production functions, $\mathrm{G}($.$) link output of each variety, 1\left(\mathrm{q}_{\mathrm{i}}\right)$ to a vector of inputs allocated to that variety $\left(\mathrm{x}_{\mathrm{i}}\right)$ and a vector of variety specific production 
characteristics $\left(\mathrm{Z}_{\mathrm{i}}^{\mathrm{q}}\right)$;

$\left(\mathrm{G}\left(\mathrm{q}_{\mathrm{i}}, \mathrm{X}_{\mathrm{i}}, \mathrm{Z}_{\mathrm{i}}^{\mathrm{q}}\right)=\mathrm{O}, \mathrm{i}=1,2 \ldots \mathrm{n}\right.$

Cassava produced by the household is either consumed or sold. For each variety, total output is at least as great as the sum of consumption and net sales $\left(\mathrm{M}_{\mathrm{i}}\right)$ :

$\mathrm{q}_{\mathrm{i}}-\mathrm{C}_{\mathrm{i}}-\mathrm{m}_{\mathrm{i}} \geq \mathrm{o}, \mathrm{i}=1,2 \ldots . . \mathrm{n}$

Finally, it is assumed that households face transactions costs $(\mathrm{t})$ when they participate in market transactions. These marketing costs encompass a wide variety of householdspecific factors, including the cost of moving tubers or processed cassava products to or from the market place where exchange takes place, credit constraints, liquidity constraints, information gaps and other household specific limitations. For simplicity, we assume that $\mathrm{t}$ is identical for both sales and purchases (e.g, unit transportation costs to and from a central market place). The households budget constraint is thus given by

$\mathrm{P}_{\mathrm{c}} \mathrm{Q}_{\mathrm{c}}+\mathrm{wl}+\sum \mathrm{k}_{\mathrm{i}}^{2}\left(\mathrm{p}_{\mathrm{i}}-\mathrm{k}_{\mathrm{i}} \mathrm{t}_{\mathrm{i}}\right) \mathrm{M}_{\mathrm{i}}-\mathrm{p}_{\mathrm{i}} \mathrm{t}-\mathrm{P}_{\mathrm{N}} \mathrm{C}_{\mathrm{N}} \geq \mathrm{O}$.

where the $\mathrm{K}_{\mathrm{i} \text { 's }}$ take values of $-1,1$, or o, depending on whether the household is a net purchaser, net seller or autarkic with respect to variety $i$. The model is solved by maximizing equation (1) subject to equations (2) -(4). Two aspects of the model are noteworthy for their uniqueness. First, the marginal rate of substitution between two varieties is a weighted sum of the marginal contribution of each variety to the total amount of each characteristics supplied. Second, these marginal rates of substitution are equated to effective prices (inclusive of marketing costs incurred)

Taken together, these features of the model's solution imply that households might simultaneously cultivate multiple varieties if certain characteristics are unique to a particular variety and marketing costs are high enough to induce autarky (Greene, 2000).

In this study data were analyzed by using Krustal Wallis statistic, binary logit model, and maximizing the households utility model subject to certain production and income constraints.

The utility models are specified implicitly as follows:

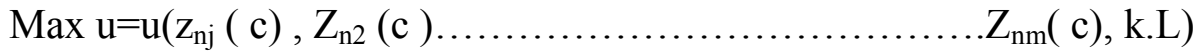

Subject to

$\mathrm{G}\left(\mathrm{q}_{\mathrm{i}}, \mathrm{X}_{\mathrm{I}}, \mathrm{Z}_{\mathrm{i}}{ }^{\mathrm{q}}\right)=\mathrm{O}, \mathrm{i}_{\mathrm{I}}=1,2$

$\mathrm{q}_{\mathrm{I}}-\mathrm{c}_{\mathrm{I}}-\mathrm{M}_{\mathrm{i}} \geq \mathrm{o}, \mathrm{I}=1,2$,

$\mathrm{P}_{\mathrm{c}} \mathrm{Q}_{\mathrm{c}}+\mathrm{wl}+\sum \mathrm{k}_{\mathrm{I}}^{2}\left(\mathrm{p}_{\mathrm{i}}-\mathrm{k}_{\mathrm{i}} \mathrm{t}_{\mathrm{i}}\right) \mathrm{M}_{\mathrm{i}}-\mathrm{p}_{\mathrm{i}} \mathrm{t}-\mathrm{P}_{\mathrm{N}} \mathrm{C}_{\mathrm{N}} \geq \mathrm{O}$.

where the variables are as previously defined in the analytical framework. To test for the significance of variety rank mean scores, the Krustal Wallis statistics was used. The Krustal-Wallis (KW) test is the non-parametric equivalent of the parametric analysis of variance.

It is applied if there are more than two samples involved and the data is at least ordinal and the samples are independent

(Macodo, 1999). The model is stated as follows:

$\mathrm{H}=12 / \mathrm{n}(\mathrm{n}+1) \sum_{J=1} \mathrm{Rj}^{\mathrm{k}} / \mathrm{nj}-3(\mathrm{n}+1)$

where $\mathrm{H}=$ the $\mathrm{KW}$ value by which the statistical significance of the means difference would be judged.

$\mathrm{n}=\mathrm{n}_{\mathrm{i}}+\mathrm{n}_{2}+\ldots . .+\mathrm{n}_{\mathrm{k}}=$ number of observations

$\mathrm{n}_{\mathrm{j}}=$ sample size for sample $\mathrm{j}$

$\mathrm{K}=$ number of samples

$\mathrm{R}_{\mathrm{j}}=$ rank sum of sample $\mathrm{j}$ 
To estimate the determinants of variety choice, the univariate dichotomous choice model was used. The model can be expressed as,

$\mathrm{P}_{\mathrm{i}}=\mathrm{p}_{\mathrm{i}}\left(\mathrm{Y}_{\mathrm{i}}=1\right)=\mathrm{G}\left(\mathrm{X}_{\mathrm{i}, \phi}\right)_{\mathrm{i}}=1,2$

The equation states that the probability that the ith farmer will adopt a technology, say improved cassava variety TMS 30572, $\mathrm{p}_{\mathrm{i}}\left(\mathrm{Y}_{\mathrm{i}}=1\right)$, is a function of the vector of explanatory variables $X_{i}$ and the unknown parameter vector $\phi$. Because the functional form of $\mathrm{G}$ is unknown, practical applications of the model are not feasible (Ameniya, 1981).Therefore an explicit functional specification of $\mathrm{G}$ is necessary .These functional relationships often specified are the linear probability probit, and logit models. An important question in this context is the appropriateness of the choice of functional forms used and the selection criteria among alternative model specifications. Choice of model can be justified on the basis of underlying theory (Capps and Kramer, 1985).Ameniya (1981) states that the statistical similarities between the logit and probit models make such a choice difficult . Choice of any one model is therefore, not dominant and must be evaluated after the fact on statistical grounds. For this study, the statistical criteria used for evaluating alternative specifications were, the percentage of correct predictions, Mc Fadden's $\mathrm{R}^{2}$, and the likelihood ratio test.

\section{RESULTS AND DISCUSSION}

\section{Use of improved and local cassava varieties}

Table 1 represents a breakdown of farmers by the type of cassava cuttings they used in the 2003 / 2004 cropping year.

Result shows that a larger proportion(32\%) of the farmers planted recycled improved varieties and local variety, followed by $25 \%$ of the farmers that planted improved and recycled improved varieties. A very low proportion $(5 \%)$ of the farmers planted only improved cassava varieties. This result implies that the use of only improved cassava varieties is not widespread in the study area. Rather the farmers are still combining the improved varieties and the local varieties, and this may be due to the high costs associated with the improved cassava cuttings in Imo State.

Table 1: Distribution of farmers by use of different types of cassava cuttings in Imo State, 2003/2004

Type of cuttings Frequency Relative frequency

Planted

(TMS) 30572 only

4 (2) 1425 only

30555 only

improved varieties only

Recycled improved varieties only

Improved and Recycled improved varieties

Local variety only

(TMS) 30572 and local variety

4(2) 1425 and local variety

30555 and local variety

Improved varieties and local

Variety

Recycled improved varieties and

Local variety

Total

Source: Survey data, 2004
0

$0 . .0$

0.0

0.0

5.0

8.33

25.0

0.0

4.17

3.33

5.83

16.67

38

31.67

120 


\section{Cassava Production and yields by variety}

Table 2 provides data on cassava area shares and yields by variety for the 2003/2004 cropping year. In Imo State, five different types of cassava cuttings are commonly planted. Yields indicated by farmers for TMS $30572(22.9 \mathrm{t} / \mathrm{ha})$ were higher than yields for recycled improved variety (19.8t/ha),30555(19.0t/ha), 4 (2)1425 (17.6t/ha) and local variety $(16.3 \mathrm{t} / \mathrm{ha})$. This finding is similar to those of Nweke et al (1998) in their study on cropping systems and agro-economic performance of improved cassava in humid ecosystem. Although the yields for local variety is low, it Still has the highest areas share. This is because of the high cost of hybrid cuttings, low storability and quality of the tubers as indicated by the farmers.

Table 2. Cassava area shares and yields by variety in Imo State, 2003/2004.

$\begin{array}{lll}\begin{array}{l}\text { Cassava } \\ \text { Variety }\end{array} & \begin{array}{l}\text { Area share } \\ (\%)\end{array} & \begin{array}{l}\text { Yield } \\ \text { (ton/ha) }\end{array} \\ \text { TIMS (30572) } & 11.5 & 22.9 \\ 4(2) 1425 & 3.0 & 17.6 \\ 30555 & 9.3 & 19.0 \\ \text { Local variety } & 42.3 & 16.3 \\ \text { Recycled improved varieties } & 33.9 & 19.8 \\ \text { Total } & 100\end{array}$

Source: Field survey data, 2003/2004 cropping year.

\section{Analysis of farmers' assessment of cassava varieties and characteristics.}

Thirteen characteristics thought to be potentially important were identified during pilot survey. For each of the characteristics farmers were asked to rate each variety using a 3-point scale : (1) bad, (2) better, and (3) excellent. Using the ratings given by farmers, Kruskal-Wallis (KW) non-parametric tests were conducted to compare farmer assessments of individual varieties. These tests, the most appropriate for ordinal data of the kind used here (Conover, 1999; Hintze, 2003), entailed a comparison of the sum of rankings obtained from pooling the ratings data of the different varieties. The null hypothesis for the KW test was that there is no significant differences in the rankings of varieties for a particular characteristic. The null hypothesis is rejected if the P-value is less than the specified level of the test.

The results of these analyses are summarized in Table 3 . The results indicate that a number of statistically significant differences exist among varieties, but that no variety is superior for all characteristics This implies that farmers face trade-offs and that they have to weigh up how they value each characteristics and each variety with respect to the characteristic considered valuable.

Improved varieties were perceived to outperform local varieties for all but three characteristics, and in those three cases, the differences among varieties were significant. For four of the characteristics, differences were not significant at the 5\% level, which could help to explain the low adoption of improved cassava varieties in Imo State. Among individual varieties, TMS 30572 tended to dominate the other three for most characteristics. However, given the agronomic advantages of the improved varieties, their low adoption rates in the state imply that socio economic and demographic characteristics of farming households were more important in explaining the adoption behaviour of farmers than the agronomic characteristics of cassava varieties. These factors include the effectiveness of extension services, farm household income, household size, age and education level of household head, land tenure arrangements, and the migrant status of the farming household. 
However, results of the non-parametric tests show that farmers perceive differences among varieties for some of the characteristics they consider to be important. Varieties that are widely used tend to be regarded as having good performance with respect to the most important characteristics. The ratings obtained by the more popular varieties indicate that -they do not perform badly, but they are not the best. These findings are similar to those of Hintze $(2002,2003)$. No statistically significant differences in labour or non-labour input requirements were observed between improved and local cassava varieties by farmers. The farmers in the state did not believe that improved varieties require more effort or care than local varieties.

Table 3. Rank Mean Scores Per Variety and Non-parametric test results Mean Scores

$\begin{array}{lllll}\text { Variety characteristic TMS } 30572 & 4(2) & 1425 & 30555 & \text { Local }\end{array}$

$\begin{array}{lllll}\text { Drought resistance } & 2.65 & 2.43 & 2.24 & 2.41\end{array}$

Disease resistance $2.61 \quad 2.01=2.37$

Disease resistance $\quad 2.61$

Pest resistance

1.87

$2.01 \quad 2.37$

2.00

$\begin{array}{ll}1.52 & 1.65\end{array}$

2.78

$\begin{array}{ll}2.52 & 2.49\end{array}$

2.07

$\begin{array}{ll}1.96 & 2.17\end{array}$

1.66

$2.45 \quad 2.13$

2.09

$2.41 \quad 2.38$

1.94

$\begin{array}{ll}2.55 & 2.52\end{array}$

2.28

$\begin{array}{ll}2.06 & 2.19\end{array}$

2.02

$2.10 \quad 2.15$

2.88

$0.94 \quad 0.98$

2.94

$2.41 \quad 2.37$

2.35

p-value

Garri quality

1.07

2.48

2.49

$2.29 \quad 2.33$

2.38

$0.022 *$
$0.008 * *$

Non-labour input

requirement

(.

* Significant at 0.05 level

**Significant at 0.01 level

\section{Determinants of varietal choice}

Table 4 presents the empirical results of the binary logit model estimated for the area. The model fits the data well, as indicated by the proportion of correctly predicated observations, by the computed values of the Mc Fadden's $\mathrm{R}^{2}$, and by the fact that the parameter estimates are generally of the expected sign.

Multi collinearity problems induced by the creation of the characteristics dummies precluded the inclusion of all characteristics variables, consequently, we experimented with multiple,combinations of variables, and the results presented in table 4 are representative of the outcome of these experiments.

Results shows that, four variety characteristics -disease resistance, tuber size, early maturity and harvesting ease, consistently emerged as having a significant positive impact on improved cassava variety adoption (as well as the largest marginal effects of any of the explanatory variables.) 
Table 4 Binary logit estimates of adoption of improved cassava varieties in Imo State, 2003/2004.

$\begin{array}{llll}\text { Variable } & \text { Parameter } & \text { P. value } & \text { Margin } \\ \text { Constant } & 5.413 & 0.009 & 0.418 \\ \text { Farm size } & 0.471 & 0.125 & 0.029 \\ \text { Household size } & -0.165 & 0.037^{*} & 0.208 \\ \text { Extension contact } & 0.317 & 0.004^{* *} & 0.312 \\ \text { Educational level } & 0.205 & 0.041^{*} & 0.293 \\ \text { Marketing costs } & 0.359 & 0.044^{*} & 0.381 \\ \text { Disease resistance } & 1.092 & 0.007^{* *} & 0.438 \\ \text { Stand establishment } & 2.107 & 0.324 & 0.177 \\ \text { Tuber size } & 1.309 & 0.027^{*} & 0.349 \\ \text { Early maturity } & 2.603 & 0.009^{* *} & 0.291 \\ \text { Harvesting ease } & 1.466 & 0.034^{*} & 0.306 \\ \text { Garri quality } & 0.388 & 0.187 & 0.021 \\ \text { Log -likelihood } & -87.31 & & \\ \text { Mc Fadden's R } & 0.719 & & \\ \text { Percentagepredicted } & & & \end{array}$

Percentage predicted correctly 89

*Significant at 0.05 level

**Significant at 0.01 level

Source: summarized from Computer output

Also, marketing costs and three of the socio - economic and demographic characteristics of farmers - household size, extension contact, and education level consistently emerged significant, implying that they equally determine the adoption behaviour of the cassava farmers.

\section{CONCLUSION}

This study investigated the factors contributing to the low levels of adoption of improved cassava varieties in Imo State. We considered a multitude of varietal and socio - economic characteristics. Non -parametric tests indicated that farmers do perceive significant differences among varieties. Improved varieties dominate in terms of most variety characteristics, but are regarded as inferior in terms of pest resistance, root storability and garri quality .

Results also showed that not only varietal characteristics determine adoption levels of improved cassava, but also extension contact has a significant influence on adoption behaviours of farmers. However, since the adoption rates of the improved cassava varieties are still low, it suggests that there are still technology information dissemination deficits and inadequacy of the improved cassava cuttings in Imo state. Ameliorating deficits of this sort falls on the state extension service.

However, given the perceived ineffectiveness of the state extension service in information dissemination and farm input distribution, it is difficult to imagine that these deficits, and hence low levels of improved cassava varieties adoption in Imo State are likely to be reversed in the foreseeable future.

\section{REFERENCES}

Ameniya, T (1981). Qualitative response models: a survey Journal of Economic Literature, Vol.19,pp.1483-1536.

Capps, J.O and Kramer, R(1985). Analysis of food stamp participation using 
qualitative choice models. American Journal of Agricultural Economics, Vol. 67,pp.49-59.

Conover, W.J (1999). Practical Non- Parametric statistics. Wiley series in Probability and statistics, Applied probability and statistics section Wiley, New York Jersey.

Greene W (2002), Econometric Analysis. Prentice Hall, Upper Saddle River, New

Hintze, L.H(2002).Variety characteristics, transition cost and maize adoption in Honduras. Ph. D Dissertation, North Carolina State University, Raleigh North Carolina.

Hinze, L.H Renkow M, and Sain, G. (2003). Variety Characteristics and maize adoption in Honduras. Elsevier journal of agricultural economics, Vol. 29,pp.307-317.

IITA (1987). Annual Report. Resources and crop management programme. IITA Ibadan, Nigeria.

IITA (1998). IITA Medium Term plan, 1999-2003. IITA Ibadan, Nigeria.

Ladd G.W and Suvannunt, V. (1998). A model of consumer goods characteristics. American Journal of Agricultural Economics, Vol. 58, no.3,504-510.

Macodo, D.S (1999). "Statistics for Decision making” Linnet Paul Publications, Port Harcourt, pp.198-199.

Nweke F.I, Ezumah H.C and Spencer D.S.C (1998). Cropping Systems and agroeconomic performance of improved cassava in a humid forest ecosystem. RCMP Research Monograph 2. IITA Ibadan, Nigeria.

Polson R.A and Spencer D.S.C (1992). The technology adoption process in subsistence agriculture: the case of cassava in South western Nigeria . IITA Research no.5, pp.12-16.

Renkow M, Hallstorm D, Karanja D.D (2001). Rural infrastructure , transaction costs, and market participation in Kenya. Journal of Development Economics, Vol.70, no.1,pp.16-23. 